\title{
IMPLEMENTASI EVALUASI PEMBELAJARAN OLEH DOSEN PRODI PENDIDIKAN AGAMA KRISTEN DI STT KRISTUS ALFA OMEGA SEMARANG SEMESTER GANJIL TA 2018/2019
}

\author{
David Priyo Susilo \\ (Dosen Prodi Pendidikan Agama Kristen: david.priyo69@gmail.com)
}

\begin{abstract}
One of the duties of the lecturer is to evaluate learning. Lecturers who conduct evaluations of learning well will encourage students to have self-confidence, improve achievement and have hopes of achieving the future. Lecturers as good evaluators have a big impact on students. Evaluation of good learning is done through a good process. First, the measurement is preceded by marking using numbers that are

learned by using tests to measure cognitive aspects and using non-tests to measure affective and psychomotor aspects and then interpreting and evaluating. Second, an assessment is carried out, namely the interpretation of the measurement results, for example students who have a value of 90 are included in the good. Evaluation of learning, namely the provision of data based on measurement and assessment. So the method used in this study is descriptive research method about the Implementation of Learning Evaluation by Lecturers at STT Kristus Alfa Omega Semarang This Odd Semester 2018/2019 Academic Year wants to know the level of learning evaluation conducted by lecturers of Christian Education study programs at STT Kristus Alfa Omega Semarang without making comparisons or relationships with other variables.The sound of the first hypothesis is thus, the sound of the first hypothesis is the level of the expected level of implementation of learning evaluation by the lecturer of odd semester Christian

Education Education Study Program 2018/2019 in STT Kristus Alfa Omega Semarang in the medium category equal to $60 \%$ of the maximum value not accepted.Based on the results of the research item which states "Lecturers provide criteria for assessing numbers: very good, good or not good" has a very low value of 54. This indicates that the lecturer does not provide assessment criteria. The results of this study which stated "Lecturers provide information to students about things that need to be improved" this gets a low score, meaning that the lecturers do not provide information to students about things that need to be improved in relation to the results of tests and non tests that they do.
\end{abstract}

\section{A. PENDAhULUAN}

Berdasarkan pengamatan peneliti sebagai dosen Program Studi Pendidikan Agama Kristen di STT Kristus Alfa Omega Semarang, ${ }^{1}$ masih terdapat dosen yang kurang melakukan pengimplementasian evaluasi pembelajaran. Hal ini dibuktikan dengan melakukan pengukuran berbagai aspek hanya dengan menggunakan tes, padahal tes lebih tepat digunakan untuk mengukur aspek afektif dan psikomotorik. Masih terdapat dosen yang kurang memberikan laporan penilaian secara transparan atau tidak disertai dengan rincian penilaian, hal ini mengakibatkan mahasiswa kurang menerima hasil penilaian secara legowo karena tidak disertai dengan rincian hasil penilaian.

Identifikasi masalah yang pertama adalah masih terdapat dosen yang kurang mengimplementasikan evaluasi pembelajaran. Kedua, masih terdapat dosen yang kurang melakukan pengukuran secara tepat, hal ini dibuktikan dengan melakukan pengukuran berbagai aspek hanya dengan menggunakan tes, padahal tes lebih tepat digunakan untuk mengukur aspek afektif dan psikomotorik. Ketiga, masih terdapat dosen yang kurang memberikan laporan penilaian secara transparan atau tidak disertai dengan rincian penilaian, hal ini mengakibatkan mahasiswa kurang menerima hasil penilaian secara legowo karena tidak disertai dengan rincian

\footnotetext{
${ }^{1}$ Hasil pengamatan peneliti sejak tahun 2013-2018.
} 
hasil penilaian. Keempat, masih terdapat dosen kurang memberikan umpan balik, hal ini dibuktikan dengan dosen tidak mengembalikan lembar tugas yang dikumpulkan mahasiswa dan hanya memunculkan nilai. Kelima, masih terdapat dosen yang hanya menggunakan tes essay dalam mengevaluasi mahasiswa, hal ini membuat mahasiswa jenuh dan mengerjakan asalasalan. Ketujuh, masih terdapat dosen kurang menggunakan variasi tes yang dapat digunakan untuk mengukur aspek kognitif mahasiswa. Kedelapan, masih terdapat dosen yang menggunakan tes tetapi hanya mengukur pemahaman mahasiswa, tidak sampai mengukur perkembangan kognitif mahasiswa yaitu menerapkan dalam praktik hidup mahasiswa. Kesembilan, masih terdapat dosen yang lebih memilih menggunakan tutorial daripada menggunakan remedial untuk memberi kesempatan kepada mahasiswa yang mengalami kegagalan dalam ujian. Kesepuluh, masih terdapat dosen yang belum memahami tentang pengayaan bagi mahasiswa yang berprestasi sehingga mereka merasa bosan karena mereka memiliki kemampuan di atas rata-rata teman-temannya tetapi diberikan materi yang sama.Tujuan penelitian ini untuk mengetahui tingkat implementasi evaluasi pembelajaran oleh dosen Program Studi Pendidikan Agama Kristen di STT Kristus Alfa Omega Semarang Semester Ganjil Tahun Ajaran 2018/2019.

\section{B. METODOLOGI}

Metode penelitian yang digunakan dalam penelitian ini adalah metode penelitian deskriptif. Penelitian deskriptif adalah penelitian yang dilakukan untuk mengetahui nilai variabel mandiri, tanpa membuat perbandingan atau penghubungan dengan variabel lainnya. ${ }^{2}$ Jadi, metode penelitian deskriptif tentang implementasi evaluasi pembelajaran oleh dosen di STT Kristus Alfa Omega Semarang Semester Ganjil Tahun Ajaran 2018/2019 ini ingin mengetahui tingkat evaluasi pembelajaran yang dilakukan oleh dosen program studi Pendidikan Agama Kristen di STT Kristus Alfa Omega Semarang tanpa membuat perbandingan atau hubungan dengan variabel lainnya.

\section{PEMBAHASAN}

1. Dosen Melakukan Evaluasi Pembelajaran dengan Tepat

a. Dosen Melakukan Pengukuran

Evaluasi sering diidentikkan dengan pengukuran (measurement) dan penilaian (assessment), walaupun ketiga istilah ini sebenarnya terdapat perbedaan. Perbedaannya dapat dilihat dari beberapa kutipan sebagai berikut: Measurement refers to the process of assigning numerals to events, object etc. ${ }^{3}$ Pengukuran dapat diartikan proses penandaan menggunakan angka bagi suatu peristiwa, objek dan sebagainya. Kepentingan pengukuran menggunakan angka adalah untuk memberikan gambaran tentang karakteristik objek tertentu.

Pengukuran atau measurement adalah proses penetapan angka dengan cara yang sistematik untuk menyatakan terhadap keadaan individu atau mendeskripsikan performance

\footnotetext{
${ }^{2}$ Sofyan Siregar, Statistik Parametrik Untuk Penelitian Kuantitatif (Jakarta; Bumi Aksara, 2014), 15.

3 J. Swarupa Rani, Educational Measurement and Evaluation (India: Discovery Publishing
} House, 2007), 12. 
peserta didik. ${ }^{4}$ Contoh pengukuran adalah pendidik melakukan tes bagi peserta didik dan hasil tes tersebut diwujudkan dalam angka (bersifat kuantitatif). Pengukuran adalah membandingkan sesuatu dengan ukuran (bersifat kuantitatif). ${ }^{5} \mathrm{Jadi}$, pengukuran adalah membandingkan sesuatu dengan menggunakan angka secara sistematik untuk memberikan gambaran tentang karakteristik peserta didik yang bersifat kuantitatif (diwujudkan dalam angka).

b. Dosen Melakukan Penilaian

Berikut beberapa pendapat tentang definisi penilaian:

Joughin mengutip, "Assessment means work (e.g examination, assignment, practical, performance) that a student required to complete for any one or a combination of the following reason: the fulfillment of educational purposes (for example, to motivate learning, to provide feedback); to provide a basis for an official record of achievement or certification of competence; and or to permit grading of the student. "Penilaian berarti pekerjaan (misalnya ujian, tugas, praktis, kinerja) yang harus diselesaikan oleh seorang peserta didik atau kombinasi dari alasan berikut: pemenuhan tujuan pendidikan (misalnya, untuk memotivasi pembelajaran, memberikan umpan balik); Memberikan dasar untuk mencatat prestasi atau sertifikasi kompetensi secara resmi. ${ }^{6}$

Penilaian (assessment) adalah kegiatan menafsir data hasil pengukuran berdasarkan kriteria tertentu dan bersifat kualitatif. Contoh: Pendidik melakukan penafsiran hasil pengukuran nilai mahasiswa dalam TAS mata kuliah Psikologi Pendidikan adalah A (90) dan termasuk dalam kriteria baik (menguasai). Menurut Arikunto, "Penilaian adalah mengambil suatu keputusan terhadap sesuatu dengan ukuran baik buruk (bersifat kualitatif)". ${ }^{7}$ Jadi, penilaian adalah kegiatan menafsir data hasil pengukuran (bersifat kualitatif), kegiatan ini untuk mencatat prestasi dan kompetensi peserta didik. Penilaian juga dapat dikatakan suatu pekerjaan yang berkaitan dengan pemberian informasi berkaitan dengan performance peserta didik yang dapat dijadikan dasar bagi pengambilan keputusan.

Penilaian ini dilakukan dengan menggunakan ukuran kuantitatif dan diinterpretasikan dalam bentuk kualitatif. Penilaian bersifat relatif, hal ini terjadi karena penilaian dipengaruhi oleh banyak faktor. Penilaian tidak terhindar dari kesalahan, hal ini dapat disebabkan oleh, alat ukur yang kurang baik, pribadi yang melakukan penilaian (adanya unsur subjektifitas, kecenderungan untuk memberikan penilaian secara murah atau mahal, adanya hallo-effect, yaitu adanya kesan penilai terhadap peserta didik, adanya pengaruh hasil yang telah diperoleh sebelumnya dan kemungkinan yang lain yaitu kesalahan dalam menjumlahkan hasil penilaian.

\section{c. Dosen Melakukan Evaluasi Pembelajaran}

Evaluasi didahului penilaian dan penilaian didahului pengukuran. ${ }^{8}$ Evaluasi adalah rangkaian kegiatan guna meningkatkan kualitas, kinerja, atau produktivitas suatu lembaga dalam melaksnakan programnya. ${ }^{9}$ Jadi, evaluasi (evaluation) adalah proses penyediaan informasi yang dapat dijadikan sebagai pertimbangan dalam mengambil keputusan. Evaluasi

$2-4$

${ }^{4}$ Eko Putro Widoyoko, Evaluasi Program Pembelajaran (Yogyakarta: Pustaka Pelajar, 2011),

${ }^{5}$ Suharsimi Arikunto, Dasar-dasar Evaluasi Pendidikan (Jakarta: Bumi Aksara, 2013), 3.

${ }^{6}$ Joughin, Gordon, Assessment, Learning, Judgement in Higher Education (Australia: Springer, 2009), 14

${ }^{7}$ Suharsimi Arikunto, Dasar-dasar Evaluasi Pendidikan (Jakarta: Bumi Aksara 2013), 3.

${ }^{8}$ Eko Putro Widoyoko, Evaluasi Program Pembelajaran (Yogyakarta: Pustaka Pelajar 2011),

$2-4$.

${ }^{9}$ Suyanto dan Asep Jihad, Menjadi Guru Profesional (Jakarta: Esensi, 2013), 192. 
dalam pembelajaran mencakup tiga aspek yaitu: kognitif (pengetahuan apa yang telah dipelajari), afektif (sikap apa yang telah dipelajari), dan psikomotorik (keterampilan apa yang telah dipelajari). Pengukuran, penilaian dan evaluasi adalah kegiatan yang berkesinambungan seperti pendapat Griffin dan Nix. ${ }^{10}$ Kegiatan evaluasi didahului pengukuran dan penilaian.

Sedangkan pembelajaran (instruction) adalah interaksi antara pendidik, peserta didik dan sumber belajar dalam lingkungan belajar melalui penguasaan ilmu, perubahan sikap dan penguasaan keterampilan baik secara formal maupun non formal. Kata "pembelajaran" menekankan keterlibatan aspek intelektual, emosional dan sosial.

Jadi, evaluasi pembelajaran adalah kegiatan yang didahului pengukuran dan penilaian yang melibatkan pendidik, peserta didik dan sumber belajar dalam proses pembelajaran (aspek intelektual, emosional dan sosial) baik secara formal maupun non formal guna menguasai kompetensi yang diharapkan. Contoh: pendidik memanfaatkan hasil pengukuran dan penilaian guna melakukan evaluasi pembelajaran (pendidik, peserta didik, materi ajar, strategi pembelajaran, media pembelajaran bagi peningkatan mutu).

Gambaran: pengukuran, penilaian dan evaluasi adalah sebagai berikut:

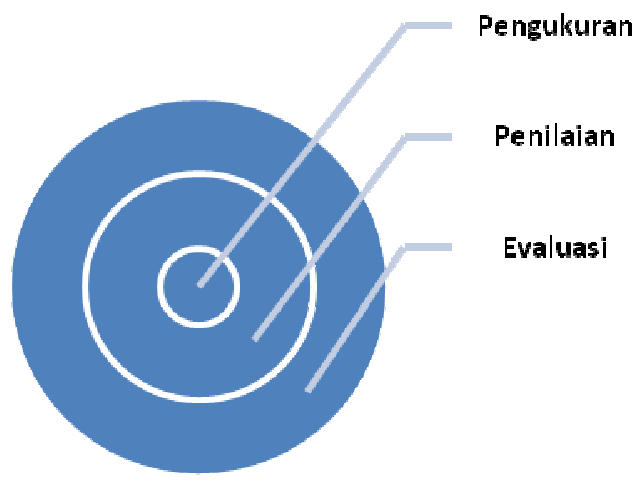

Berikut contoh perbedaan pengukuran dan penilaian

Hasil Ujian Psikologi Pendidikan

\begin{tabular}{|l|c|c|l|}
\hline \multicolumn{1}{|c|}{ Nama } & Skor & Nilai & \multicolumn{1}{c|}{ Keputusan } \\
\hline Budi & 90 & A & lulus amat baik \\
\hline Fira & 55 & E & tidak lulus \\
\hline Abi & 70 & C & lulus cukup baik \\
\hline Ajeng & 80 & B & lulus baik \\
\hline
\end{tabular}

Keterangan:

Skor merupakan hasil kegiatan pengukuran.

Kategori A, B, C, E adalah hasil kegiatan penilaian.

Klasifikasi lulus amat baik, lulus baik, lulus cukup baik dan tidak lulus.

2. Dosen Melakukan Evaluasi Pembelajaran Sesuai Prinsip Yang Tepat

a. Dosen melakukan evaluasi pembelajaran dengan menggunakan alat ukur yang valid.

Penilaian itu harus menilai apa yang ingin diketahui oleh pendidik agar ia mendapatkan informasi yang baik dan benar. Dalam penilaian, pendidik mengukur apa yang harus diukur menggunakan alat yang sesuai untuk mengukur kompetensi. Contoh jika seorang

${ }^{10}$ Eko Putro Widoyoko, 4. 
pendidik ingin meningkatkan kompetensi pengetahuan peserta didiknya, maka aspek pengetahuan yang berubahlah yang diukurnya, bukan aspek keterampilan atau sikap-sikap peserta didik.

b. Dosen melakukan evaluasi pembelajaran dengan prinsip mendidik (Educative)

Kegiatan penilaian harus mendidik peserta didik untuk mengetahui hasil belajarnya atau kompetensinya yang berubah. Hasil evaluasi itu sepatutnya memotivasi mereka untuk mengembangkan kemampuan belajar. Penilaian bukan hanya difokuskan bagi pendidik dalam memberikan angka, tetapi membantu peserta didik untuk meningkatkan kemampuannya.

c. Dosen melakukan evaluasi pembelajaran secara adil (Justice)

Semua peserta didik diperlakukan pendidik sejajar dan berharga. Setiap peserta didik mendapat kesempatan yang sama bagi penilaian. Pendidik tidak boleh membedakan peserta didiknya atas dasar latar belakang sosial, denominasi, budaya, gender, dan bahasa.

d. Dosen melakukan evaluasi pembelajaran secara terbuka (Openess).

Peserta didik berhak mengetahui cara (prosedur) apa yang digunakan pendidik dalam menilai prestasi belajarnya. Prosedur itu harus dikomunikasikan agar peserta didik merasa nyaman, aman serta termotivasi untuk belajar. Keterbukaan bukan hanya berkaitan dengan prosedur penilaian, tetapi juga berkaitan dengan penyebaran informasi, khususnya orang tua peserta didik juga dapat mengetahui kegiatan evaluasi yang akan berlangsung dan hasilnya dapat diketahui.

e. Dosen melakukan evaluasi pembelajaran secara berkesinambungan (Continuity).

Penilaian terhadap peserta didik seharusnya berlangsung secara terus-menerus, selama kegiatan belajar berlangsung (satu semester, satu tahun ajaran). Peserta didik akan mendapat kesempatan memperbaiki kelemahan yang ditemuinya dan meningkatkan hasil belajarnya.

f. Dosen melakukan evaluasi pembelajaran secara menyeluruh (Holistik).

Penilaian seharusnya meliputi kompetensi pengetahuan, kerohanian, sikap, relasi sosial dan keterampilan karya peserta didik. Oleh sebab itu, ragam tes dan alat evaluasi harus diterapkan pendidik, bukan satu jenis alat evaluasi saja. Contoh, pendidik tidak hanya menilai prestasi peserta didik saja, tetapi pendidik juga menilai sikap dan keterampilan peserta didik.

g. Dosen melakukan evaluasi pembelajaran secara bermakna (Meaningful).

Penilaian yang dipahami peserta didik, pendidik dan orang tua memiliki manfaat untuk mengetahui kekurangan dan kelebihan serta untuk meningkatkan kualitas belajar dan pembelajaran. Pendidik yang melakukan hasil evaluasi bagi peserta didik dapat mengembangkan berbagai komptensi yang dimilikinya yaitu kompetensi pedagogik, kompetensi kepribadian, kompetensi sosial dan kompetensi profesional.

h. Dosen menggunakan alat evaluasi yang reliable.

Reliabilitas berkaitan dengan konsistensi (keajegan) hasil penilaian. Penilaian yang reliable memungkinkan perbandingan yang reliable dan menjamin konsistensi. Misalnya pendidik menilai dengan unjuk kerja, penilaian akan reliable jika hasil yang diperoleh itu cenderung sama bila unjuk kerja itu dilakukan lagi dengan kondisi yang relatif sama. Petunjuk pelaksanaan dan penskorannya harus jelas. 
Penggunaan prinsip-prinsip evaluasi di atas sangat berguna mempermudah dalam menyusun alat evaluasi, pelaksanaan evaluasi dan pengembanangan kemampuan peserta didik. Sebaliknya tanpa menggunakan prisnip-prinsip di atas evaluasi tidak dapat mencapai mutu yang diharapkan.

\section{Dosen Mengevaluasi Objek Evaluasi Pembelajaran Secara Tepat}

Objek evaluasi adalah hal-hal yang menjadi pusat perhatian untuk dievaluasi. Menurut Arikunto, objek evaluasi mencakup tiga unsur, yaitu: input (peserta didik), transformasi dan output (lulusan). ${ }^{11}$

Input atau peserta didik dapat ditinjau dari beberapa hal yaitu: prestasi atau hasil belajarnya, alat yang digunakan untuk mengukur yaitu tes kemampuan (attitude test), tes kepribadian (tes yang digunakan adalah tes kepribadian atau personalitiy test), sikap-sikap (tes yang digunakan adalah skala sikap atau attitude scale dan inteligensi (tes yang digunakan tes inteligensi), bakat, kecerdasan emosi. Tes ini bertujuan untuk mengetahui kesiapan peserta didik dalam mengikuti proses pembelajaran.

a. Dosen mengevaluasi agar terjadi transformasi pembelajaran

Transformasi pembelajaran adalah proses pergantian atau pengolahan sesuatu agar berubah menjadi bentuk lain. ${ }^{12}$ Transformasi meliputi kurikulum atau materi, metode atau cara penilaian, sarana atau penggunaan media dalam proses pembelajaran, sistem administrasi atau pengelolaan pembelajaran, dan pendidik. Dosen memberikan output evaluasi pembelajaran. Output, yaitu penilaian terhadap lulusan untuk mengetahui tingkat ketercapaian/prestasi belajar, tes yang digunakan yaitu tes pencapaian atau achievement test. ${ }^{13}$

\section{b. Dosen memberikan umpan balik}

Umpan balik (feedback) yaitu segala informasi tentang transformasi maupun input dan output, hal ini berguna untuk memperbaikinya (contoh: calon peserta didik yang kurang siap mengikuti pembelajaran, pendidik yang kurang handal, materi yang tidak lengkap, metode yang kurang bervariasi, sarana dan prasrana yang kurang mendukung, sistem administrasi yang kurang lancar).

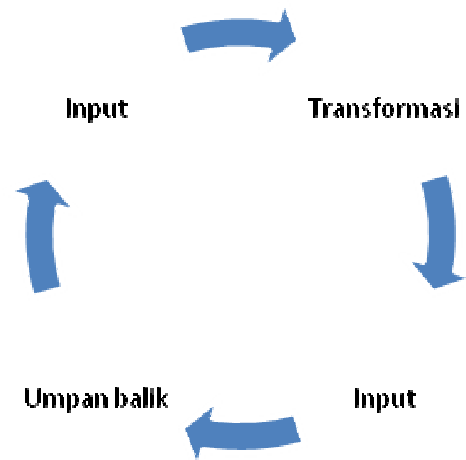

\footnotetext{
${ }^{11}$ Suharsimi Arikunto, 4-5.

${ }^{12}$ Suharsimi Arikunto, 5.

${ }^{13}$ Ibid., 34-37.
} 
4. Dosen Menggunakan Tes Untuk mengukur Kemampuan Kognitif

Tes merupakan salah satu cara untuk menaksir besarnya kemampuan seseorang secara tidak langsung, yaitu melalui respons atau pertanyaan. ${ }^{14}$ Tes adalah alat yang digunakan untuk mengukur banyaknya pengetahuan yang diperoleh individu dari suatu bahan pelajaran yang terbatas pada tingkat tertentu. Tes juga diartikan salah satu prosedur evaluasi yang komprehensif, sistematik dan objektif yang hasilnya dapat dijadikan sebagai dasar bagi pengambilan keputusan dalam proses pembelajaran. ${ }^{15}$

Jadi, tes adalah salah satu alat untuk mengukur kemampuan peserta didik dan hasilnya dapat dimanfaatkan bagi pengambilan keputusan.

a. Dosen menggunakan instrumen tes sebagai alat ukur evaluasi pembelajaran.

Sebagai alat pengukur prestasi belajar peserta didik. Prestasi belajar ini adalah tingkat perkembangan atau kemajuan yang telah dicapai peserta didik setelah mengikuti proses pembelajaran dalam jangka waktu tertentu. Dosen menggunakan instrumen tes sebagai motivator. Sebagai motivator dalam pembelajaran, hasil tes dapat dijadikan sebagai umpan balik berupa nilai untuk meningkatkan intensitas kegiatan belajar peserta didik.

b. Dosen menggunakan instrumen tes untuk memperbaiki kualitas pembelajaran.

Sebagai alat yang dijadikan untuk memperbaiki kualitas pembelajaran. ${ }^{16}$ Ciri-ciri tes yang baik, antara lain: validitas (sebuah tes dikatakan valid jika tes dapat mengukur apa yang hendak diukur atau dapat menggambarkan data yang sebenarnya/ketepatan). Reliabilitas (jika hasil tes menunjukkan ketetapan), objektivitas (bebas dari unsur pribadi), praktikabilitas/practicability (mudah pengadministrasiannya, mudah dilaksanakan, mudah pemeriksaannya, dilengkapi dengan petunjuk yang jelas).

Ekonomis pelaksanaan tes tidak membutuhkan biaya yang mahal, tenaga yang banyak dan waktu yang lama. ${ }^{17}$ Kriteria yang lain menurut Suyanto adalah sebagai berikut: Mengukur pokok bahasan yang esensial. Memiliki nilai aplikasi (penerapan), berkelanjutan (meningkatkan kemampuan peserta didik) dibutuhkan untuk mempelajari materi ajar yang lain. ${ }^{18}$

Beberapa mata kuliah membutuhkan mata kuliah prasyarat sehingga peserta didik belum dapat mengikuti mata kuliah tersebut tanpa mengikuti mata kuliah prasyarat.

c. Dosen Menghindari Penilaian Yang Salah.

Tes terdiri dari dua jenis yaitu tes objektif (skor tes ditentukan oleh jawaban yang diberikan oleh peserta tes) dan tes subjektif (penskorannya ditentukan oleh pemberi skor), subjektivitas ini antara lain disebabkan oleh: kekurangkonsistenan penilai, hallo effect yaitu skor pendidik sebelumnya akan sangat mempengaruhi penilaiannya, pengaruh urutan pemeriksaan dimana pendidik akan cenderung memberi penilaian tinggi setelah memeriksa lembar jawaban yang memiliki nilai tinggi dan sebaliknya. Bentuk tulisan dan penggunaan bahasa akan mempengaruhi penilaian pendidik.

\footnotetext{
${ }^{14}$ Eko Putro Widoyoko, 45.

${ }^{15}$ H. Jaali dan Puji Muljono, 6.

${ }^{16}$ Ibid., 7.

${ }^{17}$ Suharsimi Arikunto, 72-77.

${ }^{18}$ Suyanto \& Asep Jihad, 212.
} 


\section{d. Dosen Menggunakan Tes Objektif}

Tes objektif, yaitu bentuk tes yang mengandung kemungkinan jawaban yang telah disusun oleh penyusun butir soal. Peserta didik hanya memilih alternatif jawaban yang telah disediakan. Kelebihan tes objektif, lebih cepat dalam pengoreksian, karena dapat menggunakan kunci jawaban, pemeriksaan dapat diserahkan kepada orang lain yang telah dilatih.

Arikunto menambahkan hal berikut: dapat mencakup bahan yang luas, dapat digunakan berkali-kali, dapat dilihat secara cepat dan objektif, petunjuk cara mengerjakannya mudah dimengerti. ${ }^{19}$

Kelemahan tes objektif, membutuhkan ketelitian dalam menyusun tesnya. Tes ini hanya menekankan kemampuan mengingat, kurang mampu mengukur kemampuan manganalisis, mensintesis dan mengevaluasi, peserta didik dapat melakukan spekulasi. Menurut Arikunto, kelemahan tes objektif adalah sering membingungkan, mudah ditebak, banyak masalah yang tidak dinyatakan hanya dengan kemungkinan benar atau salah. ${ }^{20}$

Beberapa cara untuk mengatasi kelemahan penyusunan tes objektif yaitu: memperbanyak waktu berlatih menyusun soal dan memperhitungkan faktor tebakan (soal sulit ditebak). Tes objektif terdiri dari benar atau salah, yaitu tes yang memberikan jawaban dengan menentukan pilihan, yang terdiri atas benar atau salah (true-false), cara mengolah tes benar atau salah, yaitu: sistem denda dengan rumus $s k=b$-s dengan ketentuan: $s k=$ skor $b=$ jumlah jawaban benar, $\mathrm{s}=$ jumlah jawaban salah, sistem tanpa denda dengan rumus $\mathrm{sk}=\mathrm{b}$ dengan ketentuan, $\mathrm{sk}=$ skor $\mathrm{b}=$ jumlah jawaban yang benar.

Tes objektif pilihan berganda (multiple-choice), tes ini terdiri pernyataan/pertanyaan disebut stem dan alternatif pilihan atau option. Cara mengolah skor, rumus $s k=b-s: 0-1$ dengan ketentuan: $\mathrm{sk}=$ skor $\mathrm{b}=$ jumlah jawaban benar $\mathrm{s}=$ jumlah jawaban salah, $1=$ bilangan tetap, 0 = banyaknya option.

\section{e. Dosen Menggunakan Tes Subjektif}

Tes subjektif, jawaban berbentuk uraian atau esai, ciri tes subjektif menggunakan kata uraikan, jelaskan, mengapa, bagaimana dan sebagainya. Tes subjektif biasanya tidak membutuhkan uraian yang terlau banyak, tes ini digunakan untuk membandingkan dua hal yang berbeda, menghendaki rumusan pendapat, menyatakan hubungan sebab akibat, dan membuat kesimpulan atau ringkasan. Kelebihan, mudah disiapkan dan disusun, tidak memberi banyak kesempatan untuk berspekulasi atau untung-untungan, mendorong peserta didik untuk berani mengemukakan pendapat serta menyusun kalimat yang baik dan benar, memberi kesempatan kepada peserta didik untuk mengutarakan maksudnya dengan gaya bahasanya sendiri.

Kekurangannya adalah kadar validitas dan reliabilitas rendah karena sukar diketahui segisegi mana dari pengetahuan peserta didik yang betul-betul telah dikuasai, kurang representatif dalam mewakili seluruh scope bahan pelajaran karena soalnya hanya beberapa saja, cara memeriksanya banyak dipengaruhi oleh faktor subjektivitas, waktu mengoreksinya lebih lama. ${ }^{21}$ Penggunaan tes subjektif dengan pertimbangan beberapa hal berikut: Peserta tes tidak terlalu banyak dan tes hanya sekali digunakan. Pendidik bertujuan mengetahui kemampuan peserta didik dalam bentuk tertulis. Pendidik memiliki waktu yang memadai untuk menyusun tes. ${ }^{22}$

Penggunaan tes subjektif memiliki pertimbangan-pertimbangan tertentu dan hal ini perlu dipahami oleh pendidik ketika memiliih jenis tes ini.

\footnotetext{
${ }^{19}$ Suharsimi Arikunto, 181 .

${ }^{20}$ Ibid., 181.

${ }^{21}$ Suharsimi Arikunto, 178.

${ }^{22}$ Ibid., 192.
} 
Dosen menggunakan acuan penskoran, guna memudahkan pengoreksian perlu disusun serta rambu-rambu yang akan dijadikan acuan dalam penskoran, misalnya jawaban dipaparkan dengan sesuai kunci jawaban dan diungkapkan dengan bahasa yang benar. ${ }^{23}$ Rambu-rambu penskoran (skoring guide), hendaknya memuat hal-hal berikut: pedoman yaitu aturan yang disepakati dalam mengerjakan tes, relevansi antara jawaban dengan teori, tata bahasa dan ejaan yang digunakan.

5. Dosen Menggunakan Instrumen Non Tes Untuk Mengukur Aspek Afektif dan Psikomotorik

a. Dosen Menggunakan Penilaian Observasi

Pengamatan atau observasi adalah cara mengumpulkan keterangan mengenai kemajuan peserta didik dengan melakukan pencatatan secara sistematis, logis, objektif dan rasional. Pengamatan atau observasi ini dapat dilakukan dengan cara mengamati proses dan hasil belajar (contoh: mengamati cara peserta didik belajar, mengamati sikap peserta didik dalam berpendapat, mengamati sikap peserta didik terhadap pendidik, mengamati suasana kelas, mengamati sikap peserta didik dalam mengerjakan tugas, mengamati sikap peserta didik dengan peserta didik lainnya).

Pengamatan (observasi) ini harus dilakukan dengan tujuan tertentu, sistematis (misalnya: pengamatan setiap tahap, awal diskusi, selama diskusi berlangsung dan setelah diskusi berlangsung), bersifat logis (menggunakan penalaran), kritis (mengamati hal yang memerlukan perbaikan), objektif (terbebas dari unsur subjektivitas). Observasi dapat dilakukan baik secara terstruktur (menggunakan kerangka kerja yang telah disusun sebelumnya) atau tidak terstruktur (kegiatan observasi hanya mengacu pada tujuan yang telah ditentukan sebelumnya). Menurut pelaksanaannya observasi dibedakan menjadi tiga jenis, yaitu: pertama observasi langsung (observasi yang dilakukan secara langsung terhadap obyek yang diamati), kedua observasi tidak langsung yaitu observasi yang dilakukan dengan melalui perantara, ketiga observasi partisipatif, yaitu observasi yang dilakukan dengan melibatkan observer dalam situasi objek yang diteliti.

Adapun kelebihan observasi adalah sebagai berikut: observasi dapat digunakan untuk mengamati berbagai gejala yang muncul (sangat sesuai digunakan untuk mengamati perilaku pendidik maupun peserta didik). Sedangkan kelemahannya adalah seringkali proses observasi dapat terganggu dengan hal-hal yang tidak diinginkan (misalnya: adanya kesan tidak menyenangkan dari observer) dan akan terjadi kejenuhan jika pengamatan dilakukan dalam jangka waktu yang cukup lama (misalnya: mengamati sikap dosen dalam mengajar).

\section{b. Dosen Menggunakan Penilaian Wawancara}

Wawancara adalah salah satu instrumen non tes yang menggunakan pertanyaan guna mendapatkan data sesuai dengan tujuannya. Wawancara dibagi menjadi dua, yaitu pertama wawancara bebas, responden diberikan kesempatan menjawab sesuai dengan apa yang diketahuinya dan sesuai dengan maksud pewawancara. Kedua wawancara terpimpin, dimana pewawancara telah menyusun berbagai pertanyaan dan responden menjawabnya sesuai dengan pertanyaan yang diajukan saja.

Wawancara yang baik akan mempertimbangkan hal-hal berikut: pewawancara menjalin hubungan yang baik dengan responden (sehingga terjadi komunikasi yang baik pula), pewawancara memiliki dan mengembangkan keterampilan dalam bertanya sehingga responden menjawab data yang diperlukan. Teknik wawancara ini memiliki beberapa kelebihan antara

\footnotetext{
${ }^{23}$ Suyanto \& Asep Jihad, 220.
} 
lain: hubungan pewawancara dengan respons dapat terjalin dengan baik, wawancara dapat dilakukan di semua kategori usia, wawancara dapat dilaksanakan dengan observasi, perolehan data lebih banyak dan lebih akurat dibandingkan dengan observasi.

Namun teknik ini juga memiliki kelemahan yaitu: jika pewawancara kurang terampil (memiliki kemampuan berbahasa yang baik, tingkat kesopanan yang baik) maka perolehan data sangat sedikit. Situasi dan kondisi pada saat wawancara berlangsung sangat mempengaruhi perolehan data, pewawancara juga dapat menjadi sangat subjektif.

\section{c. Dosen Menggunakan Penilaian Melalui Kuesioner atau Angket}

Jika pengamatan membutuhkan kehadiran pengamat secara langsung, maka angket tidak demikian yaitu melalui tulisan. Angket berupa pertanyaan-pertanyaan yang bertujuan memperoleh data tentang responden. Angket yang baik memiliki ciri-ciri berikut: menggunakan kalimat yang jelas (dapat dimengerti respons tanpa bias), pertanyaan tidak mengandung unsur pemaksaan, pertanyaan juga tidak menyinggung perasaan responden. Ditinjau dari respondennya, angket dibedakan menjadi dua yaitu: pertama angket langsung diisi oleh responden dan angket diisi oleh perantara (enumerator).

Ditinjau dari cara menjawabnya angket dibedakan menjadi dua yaitu: angket tertutup adalah kuesioner yang dilengkapi dengan pilihan jawaban dan kuesioner yang tidak dilengkapi dengan pilihan jawaban sehingga responden memiliki kebebasan untuk menjawab. Angket biasanya digunakan untuk mengetahui hambatan peserta didik dalam proses pembelajaran, gaya belajar, motivasi belajar, minat belajar, bimbingan belajar yang diperlukan agar peserta didik mengalami kemajuan. Adapun kelebihan angket adalah dapat memperoleh data dari sejumlah responden, pertanyaan-pertanyaan yang diajukan sama. Sedangkan kelemahannya adalah pertanyaan yang diajukan terbatas sehingga jawaban yang membutuhkan penjelasan tidak dapat diakomodir dan ada kemungkinan pengembalian angket yang tidak lengkap karena pengembaliannya tidak serempak.

\section{d. Dosen Menggunakan Penilaian Catatan Anekdot}

Catatan anekdot adalah catatan yang didasarkan pada observasi yang menjelaskan tingkah laku atau kejadian dalam situasi khusus. Anekdot ini memiliki beberapa manfaat berikut: menyediakan data yang akurat tentang perkembangan peserta didik, memperoleh kejelasan tentang perilaku peserta didik (penyebab peserta didik melakukan tindakan tertentu), melalui anekdot pendidik dapat menyesuaikan komunikasi yang tepat dengan peserta didik.

\section{e. Dosen Menggunakan Penilaian Sosiometri}

Sosiometri adalah teknik non tes yang memiliki tujuan memperoleh informasi dengan didasarkan pada data tentang hubungan peserta didik dengan lingkungan sosialnya.

Melalui data ini pendidik mengetahui apakah peserta didik disukai atau tidak di antara temantemannya. Data ini juga dapat digunakan pendidik untuk memperbaiki hubungan yang tidak baik di antara peserta didik, menentukan kelompok diskusi atau kelompok kerja, memperoleh data tentang peserta didik yang berpotensi menjadi pemimpin dalam kelompoknya.

\section{f. Dosen Menggunakan Penilaian Unjuk Kerja}

Unjuk kerja yaitu penilaian yang dilakukan dengan mengamati kegiatan peserta didik dalam melakukan kegiatan tertentu, contoh: bermain peran, memainkan alat musik, mengoperasikan suatu alat. Hal-hal yang perlu dipertimbangkan dalam penilaian unjuk kerja: Langkah-langkah kinerja menunjukkan kinerja dari kompetensi tertentu. Ketepatan aspek yang 
akan dinilai. Kemampuan-kemampuan khusus yang diperlukan untuk menyelesaikan tugas. (contoh: sebelum peserta didik diberikan tugas melakukan presentasi, maka pendidik harus memastikan peserta didik memiliki kemampuan membuat slide power point).

Kemampuan yang diamati hendaknya tidak terlalu banyak. Teknik penilaian unjuk kerja: Daftar cek atau (check list), contoh: menggunakan daftar cek baik atau buruk. Skala penilaian (rating scale), contoh: 1 = sangat tidak kompeten, 2 = tidak kompeten, 3 = cukup kompeten, $4=$ kompeten dan $5=$ sangat kompeten. Penilaian unjuk kerja adalah kegiatan peserta didik dalam melakukan sesuatu. Kegiatan peserta didik melalui langkah-langkah tertentu guna mencapai kompetensi tertentu yang diukur melalui indikator tertentu.

\section{g. Dosen Menggunakan Penilaian Skala Sikap}

Skala sikap (attitude scale), sikap adalah reaksi seseorang dalam menghadapi suatu objek. $^{24}$ Sikap adalah perasaan suka atau tidak suka yang terkait dengan kecenderungan seseorang dalam merespons sesuatu. Sikap ini terdiri dari tiga komponen yaitu: afektif (perasaan yang dimiliki seseorang atau penilainnya terhadap suatu objek), kognitif (kepercayaan atau keyakinan seseorang mengenai objek) dan konatif (kecenderungan untuk berperilaku atau berbuat dengan cara-cara tertentu berkenaan dengan kehadiran sikap objek). Objek sikap yang dapat dinilai dalam proses pembelajaran adalah sebagai berikut: sikap terhadap materi ajar, sikap terhadap pendidik, sikap terhadap proses pembelajaran (suasana pembelajaran, strategi pembelajaran, metodologi, dan teknik pembelajaran yang digunakan) serta sikap yang berkaitan dengan materi ajar. ${ }^{25}$

\section{h. Dosen Menggunakan Penilaian Portofolio}

Portofolio adalah kumpulan karya (benda yang berbentuk bukti fisik) peserta didik dalam kurun waktu tertentu yang menunjukkan usaha, perkembangan dan prestasi belajar. Contoh: kertas ulangan harian, kertas ulangan semesteran, buku pekerjaan rumah, buku pekerjaan sekolah. ${ }^{26}$ Definisi yang lain, portofolio adalah penilaian berkelanjutan yang didasarkan pada kumpulan informasi yang menunjukkan kemampuan peserta didik dalam satu periode tertentu, portofolio ini sangat terkait dengan kompetensi tertentu dalam satu mata kuliah. $^{27}$

Jadi, portofolio adalah kumpulan karya peserta didik yang menunjukkan perkembangan peserta didik dalam kurun waktu tertentu dan sangat terkait dengan pencapaian komtensi tertentu. Portofolio ini bertujuan: teaches to assess students growth and progress.Parents and teachers to communicate more effectively about a students's work. Teachers and supervisors to evaluate instructional programs. Students to become partners with teachers in the assessment process.

\section{i. Dosen Menggunakan Penilaian Produk}

Penilaian produk bukan hanya mengacu kepada terwujudnya hasil, tetapi proses yang dilakukan dengan prosedur ilmiah, mulai dari persiapan: kemampuan menyusun rencana, menggali ide dan mendesain produk dan pembagian kerja setiap orang. Penilaian: pemerataan pembagian kerja setiap anggota, pengambilan keputusan dalam memilih model, kelengkapan, warna, cara penggunaan. Estimasi biaya untuk pembelian bahan dan penyelesaian perencanaan.

\footnotetext{
${ }^{24}$ Eko Putro Widoyoko, 113.

${ }^{25}$ Suyanto dan Asep Jihad, 229.

${ }^{26}$ Suharsimi Arikunto, 254.

${ }^{27}$ Suyanto dan Asep Jihad, 233.
} 
6. Dosen Memanfaatkan Hasil Penilaian Untuk Melakukan Remedial, Pengayaan dan Memperbaiki Strategi Pembelajaran

a. Dosen Memanfaatkan Penilaian Untuk Melakukan Remedial

Remedial adalah kegiatan yang bertujuan untuk menolong peserta didik yang mengalami kesulitan dalam menguasai materi ajar. Pendidik memiliki tanggung jawab untuk melaksankan program ini. Manfaat kegiatan remedial adalah sebagai berikut: Memperbaiki cara mengajar pendidik. Memperbaiki cara belajar peserta didik. Mengubah strategi pembelajaran sesuai dengan kondisi peserta didik. Mengubah metode agar materi lebih cepat dikuasai oleh peserta didik. Menolong peserta didik yang mengalami kesulitan dalam bersosialisasi.

Adapun langkah-langkah dalam kegiatan remedial adalah sebagai berikut: Melakukan analisa kesulitan belajar yang dialami peserta didik (menanyakan kesulitan belajar yang dialami peserta didik). Menemukan penyebab kesulitan yang dialami peserta didik. Menyusun rencana kegiatan remedial (jumlah peserta didik, waktu yang diperlukan, materi remedial). Melaksanakan kegiatan remedial (fokus kepada peserta didik yang belum mengalami ketuntasan belajar).

Pendidik harus menilai sejauh mana ketuntasan belajar peserta didiknya. Remidial diberikan oleh pendidik yang memahami kekurangan peserta didik. Peserta didik yang dapat mengikuti remedial adalah peserta didik yang belum mencapai ketuntasan belajar. Bahan ajar remedial ini hanya pada bagian indikator yang belum tuntas. Wujud kegiatan remedial dapat berupa tatap muka dengan pendidik atau peserta didik dapat belajar sendiri dengan pantauan pendidik. Kegiatan remedial ini di berlangsung di luar jam belajar regular (berdasarkan kesepakatan antara pendidik dan peserta didik). Selanjutnya pendidik membuat penilaian bagi peserta didik setelah program remedial.

\section{b. Dosen Memanfaatkan Penilaian Untuk Melakukan Pengayaaan}

Pengayaan diperuntukkan bagi peserta didik yang memiliki kemampuan melebihi peserta didik lainnya dalam satu kelas (peserta didik yang lebih dulu mencapai ketuntasan belajar diantara peserta didik lainnya). Wujud kegiatan pengajayaan adalah pemberian materi tambahan, program pelatihan tertentu, tugas tertentu yang bertujuan meningkatkan kemampuan belajar peserta didik. Pelaksanaan program pengayaan dapat dilakukan pada jam pembelajaran regular atau di luar jam pembelajaran regular. Kegiatan pengayaan ini dapat dilakukan oleh peserta didik yang mengalami ketuntatasan belajar kepada temannya yang belum mengalami ketuntasan dalam belajar. Melalui latihan praktis bagi pengembangan materi.

\section{c. Dosen Memanfaatkan Penilaian Untuk Perbaikan Strategi Pembelajaran}

Hasil evaluasi dapat dimanfaatkan oleh pendidik dalam melakukan perbaikan program pembelajaran. Pendidik dapat mengambil keputusan untuk mengubah strategi pembelajaran yang bertujuan agar peserta didik dapat mencapai kompetensi dasar dan standar kompetensi yang ditargetkan. Perbaikan program ini dapat diadakan di tengah-tengah proses pembelajaran atau di akhir proses pembelajaran. Peningkatan kinerja pendidik dan kepala sekolah. Hasil penilaian dapat dimanfaatkan bagi kepala sekolah untuk melihat kinerja pendidik, mengadakan perbaikan yang diperlukan atau meningkatkan kemampuan melalui pembinaan atau supervise.

Bagi peserta didik, peserta didik dapat mengetahui kekurangannya dan kelebihannya dalam proses belajar mengajar. Arikunto berpendapat bahwa peserta didik dapat konfirmasi (penguatan), revisi (penyempurnaan). ${ }^{28}$ Peserta didik yang memiliki kekurangan membutuhkan

\footnotetext{
${ }^{28}$ Suharsimi Arikunto, 316.
} 
remedial sedangkan peserta didik yang memiliki kelebihan memerlukan pengayaan. Bagi pendidik, pendidik dapat menjadikan laporan penilaian sebagai bahan evaluasi (mengenai berbagai hal misalnya kesulitan atau kemudahan materi ajar, kesesuaian atau ketidaksesuaian metode, ketepatan penggunaan strategi pembelajaran) agar dapat dijadikan sebagai informasi bagi perbaikan di masa selanjutnya. Bagi orang tua atau wali murid, dapat mengetahui kemajuan anaknya. Bagi masyarakat, keterlibatan masyarakat dalam organisasi pendidikan melalui wadah komite sekolah. Sekolah harus membangun kepercayaan masyarakat, sehingga masyarakat dapat berpartisipasi dalam memajukan sekolah. Masyarakat juga berperan sebagai akuntabilitas publik pelaksanaan kurikulum pembelajaran.

\section{HASIL PENELITIAN}

Pengujian hipotesis deskriptif menggunakan nilai hipotesis yang diperoleh dari skor empiris dibagi dengan skor ideal dikali $100 \%$, sebab uji t tidak berlaku, karena penelitian ini merupakan penelitian populasi. Adapun bunyi hipotesis pertama yaitu Diduga Tingkat Implementasi Evaluasi Pembelajaran oleh Dosen Prodi Pendidikan Agama Kristen di STT Kristus Alfa Omega Semarang Semester Ganjil Tahun Ajaran 2018/2019 dalam kategori sedang sama dengan $60 \%$ dari nilai maksimal.

$$
\begin{aligned}
& \text { Nilai_Hipotesis }=\frac{\text { Skor_Empiris }}{\text { Skor_Ideal }} \times 100 \% \\
& \text { Nilai_Hipotesis }=\frac{1727}{4 \times 23 \times 20} \times 100 \% \\
& \text { Nilai_Hipotesis }=\frac{1727}{1840} \times 100 \\
& \text { Nilai_Hipotesis }=0,93 \times 100 \% \\
& \text { Nilai_Hipotesis }=93 \%
\end{aligned}
$$

Hasil perhitungan diperoleh nilai hipotesis sebesar $93 \%$ dari nilai maksimum, hal ini membuktikan bahwa hipotesis yang berbunyi yaitu Diduga Tingkat Implementasi Evaluasi Pembelajaran oleh Dosen Prodi Pendidikan Agama Kristen di STT Kristus Alfa Omega Semarang Semester Ganjil Tahun Ajaran 2018/2019 dalam kategori sedang sama dengan 60\% dari nilai maksimal tidak diterima.

\section{E. KESIMPULAN}

Evaluasi pembelajaran adalah kegiatan yang didahului pengukuran dan penilaian yang melibatkan pendidik, peserta didik dan sumber belajar dalam proses pembelajaran (aspek intelektual, emosional dan sosial) baik secara formal maupun non formal guna menguasai kompetensi yang diharapkan. Penggunaan prinsip-prinsip evaluasi sangat berguna mempermudah dalam menyusun alat evaluasi, pelaksanaan evaluasi dan pengembanangan kemampuan peserta didik. Sebaliknya tanpa menggunakan prisnip-prinsip evaluasi tidak dapat mencapai mutu yang diharapkan.

Berdasarkan hasil penelitian item yang menyatakan "Dosen memberikan kriteria penilaian angka: sangat baik, baik atau kurang baik" memiliki nilai yang sangat rendah yaitu 54 . 
Hal ini mengindikasikan bahwa dosen tidak memberikan kriteria penilaian. Hasil penelitian tem yang menyatakan "dosen memberikan informasi kepada mahasiwa tentang hal-hal yang perlu diperbaiki" hal ini mendapat nilai rendah artinya dosen kurang memberikan informasi kepada mahasiswa tentang hal-hal yang perlu diperbaiki berkaitan dengan hasil tes dan non tes yang dilakukannya.

Hasil penelitian item nomor 8, dosen melakukan penilaian keterampilan mahasiswa. Hal ini juga mendapat nilai kurang artinya dosen kurang melakukan penilaian keterampilan yang dimiliki mahasiswa (psikomotorik) sebagai bagian dari penilaian secara menyeluruh. Sedangkan berdasarkan hasil penelitian item nomor 6 yang menyatakan "dosen melakukan penilaian pengetahuan mahasiswa". Hal ini mengindikasikan dosen sangat baik dalam mengimplementasikan evaluasi pembelajaran yang berkaitan dengan penilaian aspek pengetahuan mahasiswa.

Hasil uji hipoetesis yang berbunyi "diduga Tingkat Implementasi Evaluasi Pembelajaran oleh Dosen Prodi Pendidikan Agama Kristen Semester Ganjil Tahun Ajaran 2018/2019 di STT Kristus Alfa Omega Semarang dalam kategori sedang sama dengan 60\% dari nilai maksimal" tidak diterima.

\section{DAFTAR PUSTAKA}

Arikunto, Suharsimi. Dasar-dasar Evaluasi Pendidikan. Jakarta: Bumi Aksara, 2013.

Gordon, Joughin. Assessment, Learning, Judgement in Higher Education. Australia: Springer, 2009.

Siregar, Sofyan. Statistik Parametrik Untuk Penelitian Kuantitatif. Jakarta; Bumi Aksara, 2014. Suyanto dan Asep Jihad. Menjadi Guru Profesional. Jakarta: Esensi, 2013.

Swarupa, Rani, J. Educational Measurement and Evaluation. India: Discovery Publishing House.

Widoyoko, Eko Putro. Evaluasi Program Pembelajaran. Yogyakarta: Pustaka Pelajar, 2011. 